\title{
Contributions to the Analysis of Building's Durability Made of Local Materials
}

\author{
Bucur Dan Pericleanu and Mihaela Pericleanu
}

\begin{abstract}
This paper presents a synthesis of research carried out by authors on local materials used in construction over time in South Eastern Romania. The earth in various forms and technologies has been a perfectible building material that by technologies and specific procedures confers resistance and structural stability. For the research the authors have selected a few specific types of buildings detailing on structural compliance, their sustainability and the factors that led to the depreciation of the building.
\end{abstract}

Keywords - durability, earthen buildings, local materials.

\section{INTRODUCTION}

The paper presents results of studies and research carried out by the authors of the constituent materials and techniques to achieve specific buildings in the south east of Romania. The earth in various forms and technologies has been a perfectible building material that by technologies and specific procedures confers resistance and structural stability.

The paper wants to emphasize the traditional materials and techniques with the aim to provide a basis for future research on the construction of cheap houses, resistant and sustainable made of characteristic local materials.

\section{MATERIALS AND TRADITIONAL TECHNIQUES}

Construction materials used throughout Dobrudja are the same, offering a unique character to the traditional architecture in this part of Romania, by adapting to the environment's changes. We identified the following few traditional building materials in Dobrudja area and some work techniques characteristic to this area.

Natural stone

Dobrudja vernacular architecture uses exclusively natural stone obtained directly from the exploitation of rock quarries - the local name given was "canara"; the construction material is obtained mainly by processing of limestone rock. In terms of structural composition of the buildings in this area, this material was used to execute the house foundations and sockets. The structures have continuous foundations under the walls, with a maximum depth of $0.50 \mathrm{~m}$ and width depending on the thickness of walls $(0.60 \mathrm{~m}-0.80$ $\mathrm{m}$ ) or more. The clay was used as binder mortar and recently lime and cement mortar took its place. Stone has other uses also: the household fencing (stone dry masonry fences or stone masonry with clay mortar), the construction of fountains or for lining basements. 


\section{sciendo}

122 Ovidius University Annals Series: Civil Engineering, Year 21, 2019

Clay

This material has been and still is the traditional construction material used in Dobrudja area. He is used in combination with vegetable waste, straw or chaff, varying in proportions. Most buildings in Dobrudja villages are made of this material but today new constructions are using clay as a construction material. This tendency of conservatism is due to the offer of the environment in which there is plenty of good soil and plant material from grain farming. Another aspect is the economic one - this material is a cheap one and is easily processed being provided almost free by the environment. These are strong arguments for conserving nowadays the clay as a building material for the population of villages.

In Dobrudja loess soils of Quaternary age are used, whose main characteristic is the relatively uniform granularity, low humidity and high porosity. Due to its property to absorb and retain substances of animal oils, vegetable and mineral, loess earth is yellow open brown and has a homogeneous appearance.

Plastic state of clay (with presence of water in the composition) allows deformation under the action of external forces and transformation through modeling in construction materials (cast in patterns) with minimal effort, without being easily damaged or modifying their volume. After drying, the modeling clay becomes hard and in the same time keeps its form gained as wet clay and also hardness and strength, thus it can be confused with the consistency and durability of other materials.

Clay shaped as earth clay, mixed with a stabilizer containing plant materials in order to increase adhesion to the substrate and avoid demolition or dryness of the walls, is found in Dobrudja used alone (as "ceamur" or "chirpici") or in combination with other traditional materials (stone, reed, cane, wood), as represented in Fig. 1.

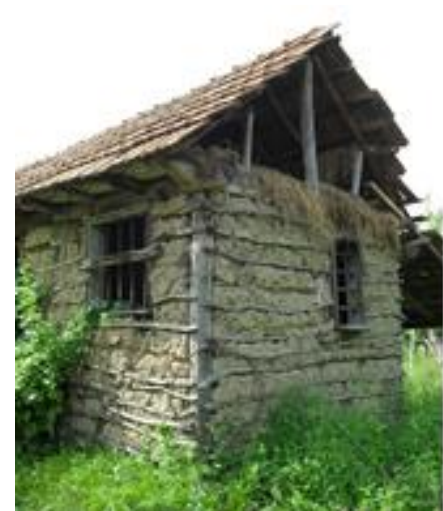

Fig. 1 Annex building made of earth in combination with wood

"Ceamur" is a smooth paste of earth mixed with chaff and / or chopped straw, kneaded with feet or with horses and cattle (for larger quantities) for about 6 hours. The pasta must be well kneaded in order to ensure homogeneity and elasticity. After kneading, small amounts of pasta shaped roughly round are made. Walls of the house rise up simultaneously in 4-5 layers, each layer about $0.50 \mathrm{~m}$ will be let to dry (between one week and ten days) and then the next layer rises until the desired height. Wall thickness is 40-50 $\mathrm{cm}$ so that they are very good thermal insulators, perfectly adapted to very hot summers and winters cold winds in this region. 
The "chirpici" represents rectangular blocks from homogeneous pasta resulting from the kneading earth mixed with straw and water (ceamur) in proportions that allow modeling using patterns. Patterns for "chirpici" were made of fir wood or poplar. The bricks obtained with these patterns were left to dry in the sun for 2-3 weeks. "Chirpic" dimensions were $10 / 20 / 40 \mathrm{~cm}$ or $20 / 20 / 40 \mathrm{~cm}$. The blocks were builded using clay mortar made of yellow earth and water or "ceamur" providing greater adhesion between clay unburnt bricks. Because manufacturing and construction technique of "chirpici" does not involve specialization and a huge mobilization of human resources, in comparison with "ceamur" technique, after 1990 this technique was largely used, demonstrating a better resistance compared to "ceamur" technique. The terms of "ceamur" and "chirpic" are Turkish words camur and kerpic.

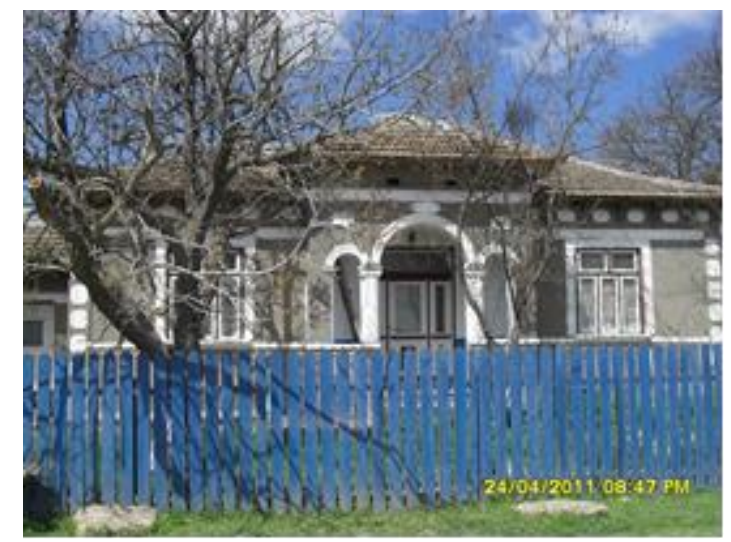

Fig. 2 Home village from Danube village, Constanta County, made by "chirpic" technique

Dry ground nozzle. This is another technique used to build houses in the Dobrudja area, but not as prevalent as the other two mentioned above. It represents a technique made of ground beaten with paddle in gradual layers over which is poured water from time to time. Each row of mud $(10,20$ or $60 \mathrm{~cm})$ is separated from the next line in a glomeration of reeds to make layers adhere to each other. The thickness of such wall reaches up to $0.8 \mathrm{~m}$ and the strength of the wall is high. Interestingly, no casings are used in order to raise these walls. For Dobrudja area, the clay was used in:

- Suprastructure construction of villages in this area - Masonry walls;

- Finishing walls;

- Construction and finishing of clay floors;

- Building and finishing ceilings;

- Coverings huts.

The walls of the houses were finished in successive layers of ground mixed with seams finely chopped chaff, horse dung and water after drying being whitewashed.

For floors houses a layer of strips of wood (pine, acacia) or a thin reed will be put, which has insulating layer, will be beaten well and leveled with a layer of ceamur of varied thickness. For finishing the floor, a layer of clay must be added. Straw and chaff are designed to increase adhesion of ceamur to the substrate and avoid sudden or excessive drying of the floor, which would lead to cracking it. The finishing layer of clay is needed in order to create a protective layer with soil rich in fat organic substances which will ensure waterproof floor (in terms of durability in time, but the floor finish must be rebuilt several times a year, generally around major Christian holidays. 


\section{sciendo}

124 Ovidius University Annals Series: Civil Engineering, Year 21, 2019

The bridge floor was also made from ceamur filling located between beams and bridge floor and finish or not. The ceamur was used as covers for huts, in a thick layer over the roof framing which will have in this case rafters and panels more frequent, sometimes covered with a layer of reeds, or fill cellars separately located from houses.

Cane / reed

Especially in the Danube Delta, for covers it is used reed and bulrush. In terms of commissioning work there are two methods of making the cover of reeds:

- Reed is harvested and tied in bundles disposed over the length of the house, from ridge to eaves and tied with wire. This technique is easy to put in work, with a small consumption of material, but such covers do not enjoy a long duration in time;

- Reed is disposed in short layers, overlapping to the framing whose purlins are often disposed, as in Fig. 3. To achieve such covers specialized craftsmen in this technique are needed, but in terms of sustainability this solution is better than the one mentioned before.

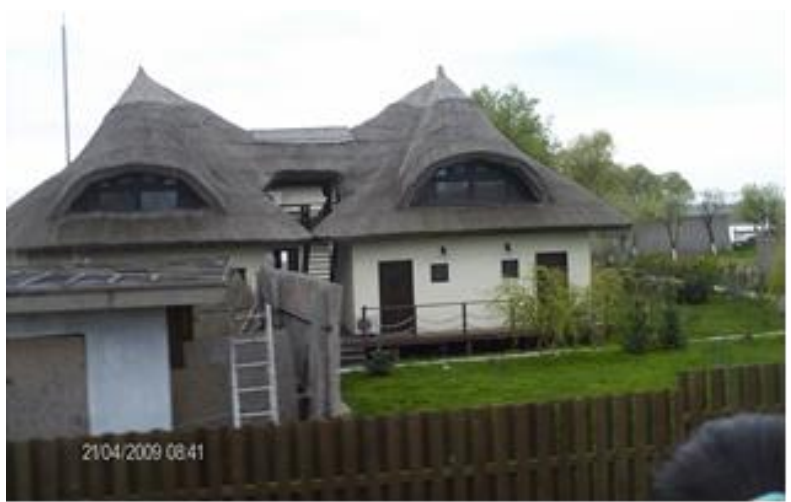

Fig. 3 Home in the Danube Delta, Maliuc town, with reed covering layers arranged in short, overlapping

\section{Wood}

Wood is another material used in traditional buildings in Dobrudja, but quite difficult to obtain because in this area forests are lacking compared to other areas of Romania. However, in the nineteenth century in Dobrudja you could find enough woods of oak, ash, lime, thus there were houses made out of wood. However, the most common usage of the building material is to achieve structures of resistance and structure of floors above ground floor. Another use, but not as widespread, it was for realizing the walls of the house by woven wattle technique supported by a fork system buried in the ground or "paianta" technique (rarely).

Brick

Brick was also used more recently (after 1950) in this area, being purchased from factories in the cities or the Gypsies as a brick produced using clay craft that they had on hands and carved it with wood patterns. Raw brick was then dried in the sun for a while, and then was burned. But the craft has not been kept in the area.

By analyzing the distribution of construction materials and techniques from the analyzed area, we may conclude that the material provided by the physical environment was predominantly clay and the technique predominantly used for house building is lifting technique of adobe walls. The oldest technique is the one of ceamur. However, the paianta technique is less used to build houses, more for agricultural annexes, and brick is a recent and more expensive material. 


\section{DEGRADATION FACTORS OF LOCAL MATERIALS}

Clay is debris of sedimentary origin, composed of fragments of rocks minerals and rocks that contain plant and animal organic matter. Degradation is the result of mechanical and chemical alteration of preexisting rocks under the action of atmospheric factors, water and ice have eroded, transported and deposited by solids results.

Disadvantages of using clay:

- It is not a standard building material, according to the origin it may have different composition and in order to prepare a proper mixture it must be set correctly features.

- The mixture of clay shrinks when it dries, which leads to cracks due to contraction. Linear shrinkage ratio is between $3 \%$ and $12 \%$ for wet processes, and between $0.4 \%$ and $2 \%$ for dry processes.

- Clay is not waterproof and therefore must be well protected from rain and frost (through eaves, wall finish).

Among the advantages of using clay as construction material we must outline:

- Clay balances humidity and can absorb and release moisture faster and to a greater extent than any other building material;

- Clay maintain heat, heavy materials for all;

- Clay saves energy and reduces environmental pollution;

- Clay is reusable, it never becomes a waste material that could pollute the environment;

- Reduces costs for materials and transportation, as a local material, and can even use excavated soil for carrying out building foundations;

- Clay is an ideal material for construction performed on own, it is not necessary that all participants are trained and required tools and machines are so expensive, making it ideal for individual buildings;

- Clay helps to keep wood and other organic materials, as long as it is combined with a large amount of plant material (straw, chaff).

The factors leading to depreciation of buildings made of clay by different techniques are the following:

- Water;

- Degradation mechanisms by biological attack;

- Action of tough winds;

- Large variations of temperature;

Freeze thaw action if the material cracks and has a certain porosity to enable it to increase their volume of frozen water.

\section{CONCLUSION}

The study on Dobrudja revealed a fascinating region by its history, held in a living habitat with a variety of populations, as nowhere in Europe do not meet, populations that have left traces in the landscape around its transition.

Construction materials used throughout Dobrudja are the same, offering traditional architecture in this area of Romania. In general, after 1950, we begin to meet in Dobrudja simultaneous use of traditional building materials characteristic of this area (such as clay, stone, straw, cane or reed) and modern materials (brick, cement, asbestos cement, concrete, metal).

As in other regions of Romania, in recent years, we can observe also in Dobrudja the trend to replace traditional materials with modern, more easily acquired and put into operation, but more expensive. Although the replacement of traditional and modern 


\section{sciendo}

126 Ovidius University Annals Series: Civil Engineering, Year 21, 2019

materials has increased, the reality of the upgrade entitles us to believe that a tendency toward vernacular architecture that keeps alive the tradition of building material adapted to its environment is manifested. Traditional materials are most appropriate to environment and climate and less expensive for people in rural areas in Dobrudja, which is characterized by modest means of living.

The huge requests shelters in developing countries can not be met using industrial materials and construction techniques, since it lacks of production capacity and financial resources. We need to make more feasible a solution-oriented; namely, the use of natural building materials available locally, which requires techniques and tools that are handy, thus ground is in this case an ideal construction material. This solution is more feasible as we are in a warm and moderate climate area, which is an advantage in terms of insulation and finishing, especially because these techniques were also used by our predecessors over time and behaved quite well in time if they were maintained. It is a perfect technical solution for our area of interest for past and our future.

\section{REFERENCES}

[1] Grămescu A. M., Barbu D. (2008), Repairing and strengthening the constructions Agir Publishing House

[2] Grămescu A.M., Gelmambet S., Pericleanu D., Drăgoi M. (2013), Determination of mechanical properties of brick masonry elements in heritage buildings, Proc. of International Symposium on Nondestructive Testing of Materials and Structures, Springer Publishing, RILEM Bookseries vol. 6, vol. II, pag. 1173 - 1178

[3] Haipal M, Török A. (1998), Petrophisical mineralogical studies on burnt sandstones, 2nd PD Symposium on Civil Engineering Budapest [Online], available at http://www.vbt.bme.hu/phdsymp/2ndphd/proceedings/hajpal.pdf

[4] Lewin S.Z. (1982-2000), Conservation of Historic Stone Building and Monuments /CHSBM - The mechanism of masonry decay trought crystallization [Online], available at [5] MINKE G. (2006), Building with Earth, Springer Publishing House

[6] Suteri G.T., Borgal C.P., Blades K. (2000), Overwiew of mortars for Canadian structure - 9th Canadian Masonry Simposium [Online], available at http://www.irc.nrccnrc.gc.ca/fulltext/mortar/paper9.pdf

Note:

Bucur Dan Pericleanu - Ovidius University of Constanta, Bd. Mamaia nr. 124, 900356-Constanta, Romania (e-mail: pericleanu.dan@univ-ovidius.ro).

Mihaela Pericleanu - Ovidius University of Constanta, Bd. Mamaia nr. 124, 900356-Constanta, Romania (corresponding author to provide phone: +40-241-619040; fax: +40-241-618372; e-mail: dragoi.mihaela@gmail.com) 